ANADOLU, J. of AARI

ISSN: 1300-0225 (Print)

E-ISSN: 2667-6087 (Online)

2019, 29 (2): 140-153

DOI: $10.18615 /$ anadolu. 660288

\title{
Ayçiçeğinde Mildiyö [Plasmopara halstedii (Farl.) Berl. and de Toni] Hastalığına Dayanıklı Genotiplerin Moleküler Markörler Kullanularak Belirlenmesi
}

\author{
Emrah AKPINAR

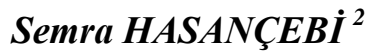 \\ Yalçın $\boldsymbol{K A} \boldsymbol{Y A}^{3 *}$ \\ ${ }^{1,2,3}$ Trakya Üniversitesi, Mühendislik Fakültesi, Genetik ve Biyomühendislik Bölümü, Edirne/TURKEY \\ ${ }^{1}$ https://orcid.org/0000-0001-5153-0392 ${ }^{2}$ https://orcid.org/0000-0003-3898-7413 ${ }^{3}$ https://orcid.org/0000-0002-9297-8633 \\ * Corresponding author (Sorumlu yazar): yalcinkaya22@gmail.com \\ Received (Geliş tarihi): 16.08.2019 Accepted (Kabul tarihi): 21.10.2019
}

\begin{abstract}
ÖZ: Ayçiçeği (Helianthus annuus L.), dünyada ve ülkemizde en önemli bitkisel yă̆ kaynaklarından biridir. Ülkemiz insanının bitkisel yă̆ tüketiminde çoğunlukla ayçiçeği yağını tercih etmesi ve son yıllarda artan yă̆ açığımız, ayçiçeğinin önemini giderek arttırmaktadır. Ayçiçeği yetiștiriciliğinde tohum verimini ve yă̆ oranını düşüren en önemli sinırlayıcı faktör mantari hastalıklar olup, etmeni Plasmopara halstedii (Farl.) Berl. and de Toni olan mildiyö hastalı̆̆l ayçiçeği üretiminde \%100’lere varan kayıplara neden olmaktadır. Ayçiçeği üretimini kısıtlayan mildiyö hastalığına karşı dayanıklı çeşitlerin geliştirilmesi ve kullanılması, ülkesel ayçiçeği üretim kaybını önleme açısından büyük önem arz etmektedir. Ayçiçeğinde bugüne kadar mildiyönün çok fazla ırkı belirlenmiş ve bunlara dayanıkl genetik materyal de geliştirilmiştir. Ancak mildiyö hastalığına dayanıklı çeşitlerin klasik ıslah yöntemleri ile geliştirilmesi hem masraflı, hem de uzun bir süreç olup, dayanıklı çeşit geliştirme çalışmalarında, biyoteknolojik yöntemler ve moleküler markör destekli seleksiyon (MAS) kullanılarak etkili ve kesin seleksiyon yapılarak, bu süreç hızlandırabilmektedir. Bu hedefler doğrultusunda yapılan bu çalışmada, Trakya Bölgesindeki tüm mildiyö ırklarına dayanıklılık sağlayan Plo ve Plarg dayanıklılık genlerinin seleksiyonunda kullanılabilecek moleküler markörlerin belirlenmesi amaçlanmıştır. Çalışmada Trakya Tarımsal Araştırma Enstitüsü’nden temin edilen, Plo ve Plarg genlerini taşıyan dayanıkl çeşitlerin hassas çeşitler ile melezlenmesi sonucu elde edilen BC4 kademesindeki 120 genotipte mildiyö hastalığına dayanıklılık testleri yapılmış ve aynı örneklerde Plo ve Plarg dayanıklılı genlerinin varlığı moleküler markörler ile belirlenmeye çalışılmıştır. Yapılan çalışma sonucunda iki markörün Plo geni ile yakın bağlantılı olduğu ve ıslah çalışmalarında seleksiyon amaçlı kullanılabileceği tespit edilmiştir. Plarg geni için ise bu çalışmada kullanılan ve önceki çalışmalarda sunulan markörlerin hiç biri yeterince ayırıcı bulunmamıştır.
\end{abstract}

Anahtar kelimeler: Ayçiçeği, Helianthus annuus, mildiyö, Plasmopara halstedii, Plø, Plarg, MAS.

\section{Determination of Downy Mildew [Plasmopara halstedii (Farl.) Berl. and de Toni] Resistant Genotypes by Using Molecular Markers in Sunflower}

\begin{abstract}
Sunflower (Helianthus annuus L.) is one of the most important vegetable oil sources in the world and in Turkey. The preference of sunflower oil in the consumption of vegetable oil increases the importance of sunflower in Turkey. Fungal diseases are the most important limiting factors sunflower yield and oil content in sunflower production and downy mildew which is caused by the Plasmopara halstedii (Farl.) Berl. and de Toni leads until 100\% yield loses. Therefore, development and the use of resistant varieties in sunflower production in Turkey help to reduce yield loses in sunflower. Several downy mildew resistance genes $(P l)$ have been identified and used in breeding for resistance cultivars. However, developing resistant varieties by classical breeding is a longer, costly and harder way and utilizing biotechnological methods and marker assistant selection (MAS) give to opportunity to accelerate the process with giving efficient and confident selection. In this study, it was aimed that to determine suitable molecular markers which will be used possibly in the selection related to Pl6 and PlArg genes conferring effective resistance against to virulent strains in Trakya region. Parents and 120 individuals at BC4 breeding level (Plo and Plarg genes sources were crossed with susceptible sunflower varieties) were used for molecular marker studies. All plant materials were also screened phenotypically by inoculation with pathogen spores. As results, two markers for Plo gene were detected as useful for MAS but no any suitable markers were found to detect Plarg gene among used markers in this and previous studies.
\end{abstract}

Keywords: Sunflower, Helianthus annuus, downy mildew, Plasmopara halstedii, Pl6, PlArg, MAS. 


\section{GİRIŞ}

Ayçiçeği (Helianthus annuus L.); Papatyagiller familyasına ait, $2 \mathrm{n}=34$ kromozomlu, gen merkezi Kuzey Amerika olan önemli bir endüstri bitkisidir. Ülkemizde ve dünyada ağırlıklı olarak bitkisel yağ elde etmek amacıyla üretilmesinin yanında, çerezlik tüketim amaciyla da üretilmektedir. Dünyada en çok ayçiçeği üreten ülkeler arasında Türkiye, 8. sirada yer almaktadır (Anonim, 2014; Kaya, 2015).

Ülkemizin bitkisel yağ tüketiminin \%60 kadarını ayçiçeği yağı oluşturmakta olup son yıllarda artan nüfus ve ayçiçeği tarım alanlarının arttırılamaması nedenleri ile ayçiçeği yağı ihtiyacı üretim ile karşılanamamaktadır. Türkiye, her ne kadar ayçiçeği üretimi açısından dünyada ilk on sırada yer alsa da, 2014 yılında yaklaşık 556 bin ton ayçiçeği tohumu ve 812 bin ton ayçiçeği yağ ithal etmiştir (Anonim, 2014).

Tarım alanlarının arttırılamaması nedeniyle üretimi arttırmanın yolu verimi arttırmak ve kayıpları azaltmaktan geçmektedir. Özellikle hastalıkların yarattığı kayıplar bölgesel olarak ekili alanları bozup tekrar ekime kadar varabilmektedir. Yabani ve kültüre alınmış ayçiçeğini olumsuz etkileyen en az 30 adet fungus, bakteri, virüs ve yabanc1 ot kaynaklı hastalık bilinmektedir. Bunlardan sadece birkaç tanesi Trakya Bölgesi'nde ekonomik zarara yol açmakla birlikte üretim açısından $\% 100$ oranında kayıplara neden olabilmektedirler. Ayçiçeğinde ürün eksilişlerine neden olan parazit bitki ve hastalıklardan ülkemiz için en önemlileri;

\section{Ayçiçeği Pası}

Puccinia helianthi Schw., bitkinin tüm toprak üstü kısımlarında görülebilen fungal bir hastalıktır. Ayçiçeği pası, ayçiçeğinde $\% 70$ oranında verim kayıplarına neden olabilmektedir. Hastalık belirtisi bitkinin çiçeklenme döneminde özellikle yaprak ve yaprak sapında, önce kahverengi sonra siyah lekeler halinde görülebilir. Enfekte bitkiler erken tohuma kalkar ve tohum kalitesi düşük olur. Sistematik enfeksiyonlarda bitki yoğun bulaşıklık barındıran yapraklarını kaybeder. Toprakta 10-12 y1l varlığını koruyabilen bir fungus olduğu için en etkin mücadelesi hastalığa dayanıklı ayçiçeği çeşitleri kullanılmasıdır (Anonim, 2008; Tan, 2010; Kaya ve ark., 2012; Škorić, 2012).

\section{Orobanş (Canavar otu)}

Orobanche cumana Wallr., Trakya'da yüksek verim kayıplarına neden olabilen bir kök parazitidir. Tohumları kahverengi renkte kapsüller içerisinde ve her kapsülde binlerce tohum barındırabilecek şekilde ayçiçeği köklerinde tutunur. Ayçiçeği ekiminden kısa süre sonra ayçiçeği köklerinde orobanş görülebilir, ayçiçeğinin çiçeklenme döneminde toprak üstüne çıkar. Her bir kökte 50 'nin üstünde orobanş sapı görülebilir. $50-60 \mathrm{~cm}$ boylanan orobanş tüm besin maddelerini ve suyunu ayçiçeği köklerinden çektiği için ayçiçeğinin boyu kısalır, tablası küçük kalır, verimi ve tohumda yağ oranı düşer. Mücadelesi, bu parazite dayanıklı çeşitlerin kullanımı ya da IMI grubu ayçiçeği çeşidi kullanılarak ve ilaçlama ile sağlanabilir (Anonim, 2008; Kaya ve ark., 2012; Škorić, 2012).

\section{Ayçiçeği Mildiyösü}

Plasmopara halstedii (Farl.) Berl. and de Toni, dünyada ayçiçeği tarımında görülen en önemli fungal hastalıktır ve \%100'e varan ekonomik kayiplara neden olabilir. Oomycetes ailesine aittir. Fide halindeyken enfekte olan ayçiçeği büyürken, patojen de dokularda gelişir. Enfekte olan bitkiler bodur kalırlar, yaprakların birbirine yaklaşması sonucu rozetleşme görülür. Enfekte bitkilerde tablaların içi tam dolmaz. Bu durum sistemik enfeksiyon olarak tanımlanmaktadır. Sistematik olmayan, lokal enfeksiyonlarda ise bitki normal gelişim gösterebilir, yapraklarda sadece lekeler görülür. Bitkinin 2-6 yapraklı dönemi sistemik enfeksiyonlara karşı hassastır. Bu dönemi sorunsuz atlatan bitkilerde daha çok lokal yaprak lezyonları görülür. Tohum ekiminden 15 gün sonrasına kadar bol yağışlı giden iklim şartlarında sistemik enfeksiyon olasılığı oldukça yüksektir. Enfeksiyon için uygun sıcaklık $15-20{ }^{\circ} \mathrm{C}$ 'dir. Oosporları toprakta 10 yıl varlığını sürdürebileceğinden ve Türkiye topraklarının yaklaşık \%90'ında görüldüğü için en etkili mücadele yöntemi hastalığa dayanıklı ayçiçeği çeşitlerinin kullanımıdır (Anonim, 2008; Kaya ve ark., 2012; Škorić, 2012; Spring, 2019). 


\section{Bitkilerde Hastalıklara Karşı Dayanıklılık}

Doğada bitkiler biyotik stres faktörlerini tanıma ve onlara karşı tepki verme mekanizması geliştirmişlerdir. Bitkiler patojen saldırısını etkili bir şekilde durdurabilmek için yapılarında bulunan fiziksel ve kimyasal engeller kadar, patojen saldırısı ile aktive olan uyarılabilir savunma mekanizmalarını da kullanırlar (Jones ve Dangl, 2006).

Bitkilerde bağışıklık sistemini uyaran mikrobiyal patojenlerin sahip olduğu yapılara, patojen ile ilgili moleküler yapılar [Pathogen Associated Mollecular Patterns (PAMPs)] veya mikropla ilgili moleküler yapilar [Microbe Associated Mollecular Patterns (MAMPs)] denir (Jones ve Dangl, 2006; Aksoy ve Öz, 2012). Bitkiler, hücre yüzeyindeki reseptörler yardımıla PAMP'ları ve MAMP'ları tanıyarak patojene karşı sahip oldukları savunma sinyallerini harekete geçirirler. Bu sinyal iletimi sonucunda hücre duvarının sağlamlaştııılması, reaktif oksijen türevlerinin ve etilen miktarının arttırılması ve hastalık gelişimi ile ilgili dayanıklılık genlerinin büyük bir bölümünün harekete geçirilmesi gibi dayanıklılık reaksiyonları hızlı ve etkin biçimde başlatılır (Jones ve Dangl, 2006; İmraz ve ark., 2015).

Bitkiler, patojen saldırısının ardından, dominant dayanıklılık genleri (R) tarafından geliştirilen, patojeni direkt veya indirekt yollarla tanımaya yarayan dayanıklılık mekanizmasını harekete geçirirler. R-proteinlerinin tetiklemesi ile meydana gelen dayanıklılık (gen-için-gen direnci) genellikle 1rk-spesifiktir ve sadece R-proteinleri tarafindan tanınan spesifik proteinleri (avr proteinleri) salgılayan patojenlere karşı etkilidir. R-genleri ile oluşturulan savunma tepkisi, saldırı bölgesinde bulunan enfekte ve komşu hücrelerde hizlı programlanmış ölümlerin (hipersensitif tepki veya HR) ortaya çıkmasına neden olur. Özellikle mildiyö gibi biyotrofik patojenlerin o bölgede etkin şekilde sınırlandırılmasında son derece etkili bir savunma stratejisidir. Şimdiye kadar çok sayıda dayanıklılık R-geni karakterize edilmiş ve bazıları ıslah çalışmaları ile başarılı biçimde kültür bitkilerine aktarılmıştır (Jones ve Dangl, 2006; İmraz ve ark., 2015). R-genlerinin belirlenmesi veya bu genler ile ilişkili moleküler markörlerin tespiti dayanıklı çeşit geliştirme kapsamındaki en önemli ihtiyaçlardandır. $\mathrm{Bu}$ nedenle tarımsal biyoteknoloji çalışmalarının oldukça önemli bir kısmını bu tip çalışmalar oluşturmaktadır.

Diğer savunma tepkileri; reaktif oksijen türleri (ROS) üretmek, hücre çeperini mekanik olarak güçlendirmek ve antimikrobiyal bileşiklerin sentezi gibi reaksiyonları kapsamaktadır. $\mathrm{Bu}$ lokal reaksiyonlar dışında, saldırıya uğrayan bitki, enfeksiyon bölgesinden uzak dokularda savunma kapasitesini artırmak üzere sistemik tepkiler de oluşturmaktadır. Sistemik olarak uyarılmış bu tepki; bitkiyi ardıl patojen istilacılarına karşı, birkaç haftadan birkaç aya kadar değişebilen bir süre için, oldukça geniş ölçekteki pek çok patojene karş1 koruyacak potansiyeldedir. Biyolojik olarak, birkaç uyarılmış sistemik savunma sistemi detaylı olarak tanımlanmıştır. Bunlar, nekrotik patojenler tarafindan tetiklenen "sistemik kazanılmış dayanıklılık" (SAR), patojen olmayan rizobakter strainlerinin köklerde kolonize olmasıyla aktive olan "uyarılmış sistemik dayanıklılı" (ISR) ve böceklerin beslenmesine bağlı olarak ortaya çıkan doku hasarlariyla uyarılan "yara uyarımlı savunma" sistemlerini kapsamaktadır. Uyarılmış savunma tepkileri, iç bağlantıları olan sinyal iletim yolları ağı ile düzenlenir ve bu yolda hormonal sinyaller olan salisilik asit, jasmonik asit ve etilen etkilidir (Aktaş ve Güven, 2005; Jones ve Dangl, 2006; Pérez-Vich ve Berry, 2010).

\section{Ayçiçeğinde Mildiyö Dayanıklılığı}

Mildiyö patojeninin 1888 yılında Plasmopara halstedii (Farl.) Berl. and de Toni olarak isimlendirilmesinden sonra Avustralya hariç tüm dünyada gözlemlenmiş ve kıtalar arasında benzer ve farklı patojen ırkları tespit edilmiştir. Bugüne kadar yapılan çalışmalarda $44 P$. halstedii 1 rk1 tespit edilmiştir (Jocic ve ark., 2010; Wieckhorst ve ark., 2010; Viranyi ve ark., 2015; Trojanová ve ark., 2016; Spring, 2019). Gulya (2007), yaptığ1 karşılaştırmalı çalışmalarda; mildiyö patojeninin yeni patojen ırklarının ortaya çıkması konusunda sürekli ve sabit olmayan bir değişim içerisinde olduğunu vurgulamıştır.

Ayçiçeğinde $P l$ genleri tarafindan sağlanan mildiyö dayanıklılığı, patojen ırkına karşı spesifik 
olmakla beraber bazı $P l$ genleri birden çok 1rka karşı dayanıklılık sağlayabilmektedir. Bugüne kadar yapılan çalışmalar göstermiştir ki; bu dayanıklılık genleri kromozomlar üzerinde belli lokasyonlarda (LG-linkage group) kümelenmiş şekilde bulunmaktadır (Viranyi ve ark., 2015).

Mouzeyar ve ark. (1995), ilk $P l$ genini $\left(P l_{l}\right)$ tanımladıklarından sonra, birçok farklı araştırmacı özellikle yabani ayçiçeği çeşitlerinde yeni dayanıklılık genleri tespit etmek ve bunları kültür çeşitlerine aktarmak için çalışmış olup, ayçiçeğinde bilinen Pl genleri, LG bölgeleri ve etkili olduğu patojen ırkları Çizelge 1 de verilmiştir.

\section{Pl Genlerinin İstenen Kültür Çeşitlerine Aktarılmasının Önemi}

P. halstedii patojeninin yol açtığı zarar ülkemizde ve özellikle ayçiçeğinin yoğun olarak ekiminin yapıldığı
Trakya Bölgesinde önemli boyutlardadır. Türkiye'nin tüm ayçiçeği ekimi yapıldığı bölgelerinde rastlanan patojen, iklim şartları ve benzeri birçok etmene dayalı olarak yıldan yıla değişen oranda, ekonomik anlamda yüksek miktarda zararlara neden olmaktadır. Hastalıkla mücadele yöntemlerinden biri olarak Metalaxyl etken maddeli kimyasalların kullanımı; ekonomik olmaması, kullanım zamanındaki iklim koşullarına göre etkisinin azalması, bazı $P$. halstedii ırklarının ilaca dayanıklılık geliştirdiğinin raporlanması (Ruiz ve ark., 2000) ve çevreye verdiği zarar nedenleriyle tercih edilmemektedir. Hastalığa dayanıklı kültür çeşidi kullanmak, $P$. halstedii patojenine karşı en başarılı ve sürdürülebilir mücadele olup, hassas fakat elit çeşitleri dayanıklılık barındıran çeșitlerle melezleyerek, istenilen dayanıklılık genine sahip geri melez jenerasyonları elde edilebilir (Kaya ve ark., 2012; Škorić, 2012; Spring, 2019).

Çizelge 1. Ayçiçeğinde bilinen Pl genleri, LG bölgeleri ve etkili olduğu patojen rrkları.

Table 1. Known Pl genes, LG regions and pathogen races at sunflower.

\begin{tabular}{|c|c|c|c|c|}
\hline $\begin{array}{l}\text { Gen } \\
\text { Gene }\end{array}$ & $\begin{array}{l}\text { Gen kaynağ1 } \\
\text { Gene source }\end{array}$ & $\begin{array}{l}\text { Gen bölgesi } \\
\text { Gene region }\end{array}$ & $\begin{array}{l}\text { Etkili olduğu patojen irkları } \\
\text { The pathogen races for effective control. }\end{array}$ & $\begin{array}{l}\text { Kaynak } \\
\text { Literature source }\end{array}$ \\
\hline$P l_{l}$ & H. annuus & LG 8 & 100 & Wieckhorst, 2011 \\
\hline $\mathrm{Pl}_{2}$ & H. annuus & LG 8 & $100,3 x x$ & Wieckhorst, 2011 \\
\hline $\mathrm{Pl}_{3}$ & H. annuus & - & - & Wieckhorst, 2011 \\
\hline $\mathrm{Pl}_{4}$ & H. tuberosus & - & - & Wieckhorst, 2011 \\
\hline $\mathrm{Pl}_{5}$ & H. tuberosus & LG 13 & $1 x x, 31 x, 32 x, 33 x, 7 x x$ & Wieckhorst, 2011 \\
\hline $\mathrm{Pl}_{6}$ & H. annuus & LG 8 & $1 \mathrm{xx}, 3 \mathrm{xx}, 7 \mathrm{x} 1,7 \mathrm{x} 2,7 \mathrm{x} 3$ & Wieckhorst, 2011 \\
\hline $\mathrm{Pl}_{7}$ & H. praecox & LG 8 & $1 \mathrm{xx}, 3 \mathrm{xx}, 7 \mathrm{x} 1,7 \mathrm{x} 2,7 \mathrm{x} 3$ & Wieckhorst, 2011 \\
\hline $\mathrm{Pl}_{8}$ & H. argophyllus & LG 13 & Avrupa'da bilinen tüm rrklar & Wieckhorst, 2011 \\
\hline $\mathrm{Pl}_{9}$ & H. annuus & - & - & Wieckhorst, 2011 \\
\hline $\mathrm{Pl}_{10}$ & H. annuus & - & - & Wieckhorst, 2011 \\
\hline$P l_{11}$ & H. annuus & - & - & Wieckhorst, 2011 \\
\hline $\mathrm{Pl}_{12}$ & H. annuus & - & - & Wieckhorst, 2011 \\
\hline$P l_{13}$ & H. annuus & LG 1 & $100,300,310,330,700,710,730,731,770$ & Wieckhorst, 2011 \\
\hline $\mathrm{Pl}_{14}$ & H. annuus & LG 1 & - & Wieckhorst, 2011 \\
\hline$P l_{15}$ & H. annuus & LG 8 & Avrupa ve Kuzey Amerika'da bilinen tüm ırklar & Wieckhorst, 2011 \\
\hline$P l_{16}$ & H. annuus & LG 1 & - & Liu ve ark., 2012 \\
\hline $\mathrm{Pl}_{17}$ & H. annuus & LG 4 & Bilinen tüm ırklar & Qi ve ark., 2015 \\
\hline $\mathrm{Pl}_{18}$ & H. argophyllus & LG 2 & Bilinen tüm 1rklar & Qi ve ark., 2016, 2017 \\
\hline$P l_{19}$ & H. annuus & LG 4 & Bilinen tüm 1rklar & Zhang ve ark., 2017 \\
\hline $\mathrm{Pl}_{20}$ & H. argophyllus & LG 8 & Bilinen tüm ırklar & Ma ve ark., 2017 \\
\hline$P l_{\text {Arg }}$ & H. argophyllus & LG 1 & Bilinen tüm urklar & Wieckhorst, 2011 \\
\hline$P l_{v}-P l_{z}$ & H. annuus & - & - & Wieckhorst, 2011 \\
\hline
\end{tabular}


Araştırılan $P l$ genlerinin bazıları 1rk spesifik olmakla beraber bazı $P l$ genleri bilinen tüm ırklara karşı dayanıklılık göstermektedir. Kültürü yapılan ayçiçeği çeşitlerine bu genlerin aktarılması patojen zararının engellenmesinin yanı sıra zamanla gen piramitleme yöntemiyle de çeşidin uzun y1llar bu dayanıklılığın üstesinden gelebilecek yeni ırklara karşı da korunma şansını arttıracaktır. İstenilen $P l$ dayanıklılık genlerinin kültür çeşitlerine aktarılması klasik sslah yöntemleri ya da MAS ile sağlanabilir. Klasik 1slah yöntemleri ile dayanıklılık genlerinin aktarılmasında bazı dezavantajlar mevcuttur. Çok sayıda bitki örneği ile çalışılmak zorunda olunması, dayanıklı bireylerin tespit edilebilmesi için sağlıklı patojenler ile birçok kez başarılı inokülasyonlar yapma zorunluluğu, çok zaman almas1 ve ekonomik olmaması bu dezavantajlardan birkaçıdır (Kaya ve ark., 2012; Škorić, 2012; Spring, 2019).

\section{Moleküler Markörler ve MAS'ın Avantajları}

Moleküler markör, genom içinde bir DNA parçasının farklılıklarını temsil eder ve bu farkl1lıklar eklenmeler, silinmeler, yer değiștirmeler, duplikasyonlar gibi olaylardan meydana gelebilir. DNA temelli moleküler markörler; taksonomi, fizyoloji, embriyoloji, genetik mühendisliği vb. alanlarda kullanılan çok yönlü araçlardır. Moleküler markörler, bir bireyin genomundaki bir gen bölgesi ya da gen bölgesi ile ilişkili DNA parçasını temsil etmektedir ve bireyler arasındaki DNA dizi farklılıklarının (polimorfik bölgelerin) saptanması prensibine dayanmaktadır. Polimer zincir reaksiyonun (PCR) keşfini takiben, DNA markörleri; gen etiketleme, genetik haritalama, genetik çeşitlilik, filogenetik analizler ve bitkisel araştırmalarda ve 1slah çalışmalarında önemli genlerin belirlenmesi konusunda yapılan MAS çalışmalarını kolaylaştırmıştır (Filiz ve ark., 2009). Yüksek yağ oranı, orobanşa, herbisitlere, hastalık ve zararlılara dayanıklılı gibi önemli verim öğelerinde, ayçiçeği ıslahında istenilen karakterlerin elde edilmesi, moleküler markör metotları yardımıyla çalışılan araştırmalardır (Kaya, 2004).
MAS için kullanılan moleküler markörler, çevresel faktörlerden etkilenmez, her zaman her koşulda stabil olup, doku tipi ya da yaşam evrelerine göre farkl1lık göstermezler. Epistatik ve pleiotropik etkilere hassas olmayip, dominant veya kodominant özellikte olabilirler ve kalıtımları basit ilkelere dayanmaktadır. Özellikle çevresel koşullardan çok etkilenen dolayısıyla fenotipik olarak gözlenmeleri zor olan karakterlerin seleksiyonunda son derece başarılı olup, doğru bir şekilde seçilmelerine olanak tanırlar. Ayrıca farklı karakterlere etki eden birden fazla genin eş zamanlı aktarımında, gen piramitlerinin oluşturulmasında, resesif genlerin seleksiyonunda, çevre faktörlerinin aşırı olduğu veya bitki gelişiminin geç dönemlerinde gözlemlenebilen karakterlerin seçiliminde de çok önemli avantajlar sunmaktadır. Herhangi bir çeşit karışıklığı durumunda kolaylıkla ayrım yapılmasında ve ticari hakların korunmasında hızlı ve etkili bir yöntemdir (Sönmezoğlu ve ark., 2010).

\section{Ülkemizdeki Islah Programlarında Moleküler Markörlere Duyulan İhtiyaç}

Dünyanın sayılı tarımsal ürün üreticilerinden olan Türkiye, tarımsal teknolojide yeterince gelişemediği için her yıl gittikçe artan oranlarda tohum ithal etmek zorunda kalmaktadır. Ülkemizde devlet destekli planlı ıslah çalışması 1891 yılında Halkalı Yüksek Ziraat Okulu'nun açılmasıyla başlamış, klasik 1slah çalışmalarına son yıllarda yaşanan teknolojik gelişmeler ve teknolojiye ulaşmanın kolaylaşması sayesinde biyoteknolojik destek ile devam edilmektedir. Tarımsal teknolojinin yardımıyla klasik 1slah yöntemlerine göre daha hızlı ve kolay sonuçlar elde edilmesini sağlayan MAS sayesinde son yıllarda yerli çeşitlerin tescili ve piyasaya girişi hızlanmış fakat halen istenen seviyeye ulaşamamıștır. Moleküler markörlerin ıslah programlarında istenen karakteri taşıyan bireylerin seçiminde kullanılması, diğer bir deyişle MAS, yeni çeşit geliştirilmesi çalışmalarında da önemli avantajlar sunmaktadır (Hvarleva ve ark., 2009; Pérez-Vich ve Berry, 2010). Islah çalışmalarında kullanılacak MAS sistemlerinin; yüksek düzeyde polimorfizmi belirleyebilmesi, kodominant 
karakter taşıması, tekrarlanabilir ve teknik olarak kolay uygulanır olması son derece önemlidir (Bretting ve Widrlechner, 1995).

İstenilen yüksek verim vb. karakterlerde yüksek heterosis için farklı genetik kaynaklara sahip kendilenmiş ebeveyn hatlara ihtiyaç vardır. Bu farklı genler çok sayıdaki tek veya çok yıllık yabani türlerde mevcut olup, bunlardaki yeni gen kaynaklarının kültürü yapılan türlere aktarılması gerekmektedir. Ancak bu aktarım türler arası melezlemelerle mümkün olup, klasik metotlar kullanılarak elde edilmesi son derece zordur. Oysa klasik ıslah çalışmalarının başarısını arttıran, bu çalışmalarda tamamlayıcı ve yardımcı bir rol oynayan MAS ile bu gen aktarımını daha kısa sürede, etkin ve ekonomik biçimde gerçekleştirmek mümkündür (Saftic-Pankovic ve ark., 2000). Ülkemizdeki 1slahçıların yurtdışından ithal ticari çeșitler ile rekabet edebilmesi için özellikle zamandan ve işgücünden tasarruf sağlayan MAS konusunda araştırmacılar ile birlikte çalışması için gerek TAGEM, gerekse TUBITAAK proje desteği sağlamaktadır.

\section{Pl Genleri için Mevcut Moleküler Markörler}

Araştırmacılar tarafindan yıllar içerisinde MAS kullanılmak amacıyla çok sayıda markör geliştirilmiştir. Perez ve Berry, (2010) ayçiçeği için üç farkl1 jenerasyon moleküler markör tanımlamışlardır. Birinci jenerasyon olarak RFLP (Restiction Fragment Length Polymorphism Kesilen Fragmentlerin Uzunluk Polimorfizmi), RAPD (Random Amplified Polymorphic DNA Değişken DNA Dizilerinin Tesedüfen Çoğaltılması), AFLP (Amplified Fragment Length Polymorphism - Çoğaltılan Fragment Uzunluk Polimorfizmi) ve genomik SSR'lar (Simple Sequence Repeats - Basit Tekrar Dizileri) geliştirilmiştir. İkinci jenerasyon markörler gen hedefli çalışacak şekilde ayçiçeğinde EST'lerden (Expressed Squence Tags - İfade Edilen Gen Segmenti) geliştirilen cDNA-RFLP probları, SNP (Single Nucleotide Polymorphism - Tek Nükleotid Polimorfizmi), Indel (Insertion/Deletion - Ekleme/ Silinme) ve SSR markörleridir. Üçüncü jenerasyon markörler, belirli bir yönde fenotipi etkileyen, alleller arasında rastgele DNA dizilim değișimlerini tespit eden markörlerdir. Ayçiçeğinde son y1llarda genotipik haritalama çalışmalarının artması sayesinde $P l$ genlerinin tespiti ve MAS çalışmaları için ağırlıklı olarak SSR ve SNP markörleri kullanılmaktadır (Pérez-Vich ve Berry, 2010; Spring, 2019).

$\mathrm{Bu}$ çalışmada kullanılacak markörlerin seçimi, bölgedeki $P$. halstedii 1rkları için herhangi bir ark ayrımı çalışması yapılmadığı için halihazırda Trakya Tarımsal Araştırma Enstitüsü (TTAE) tarafından klasik ıslah çalışmalarında kullanılan mevcut ebeveyn hatlarının sahip olduğu bilinen $P l$ genleri baz alınarak literatür taraması sonucu yapılmıştır.

\section{MATERYAL VE METOT}

\section{Bitki Materyali}

$\mathrm{Bu}$ çalışmada kullanılan bitki materyali; TTAE tarafından ayçiçeği ıslah programlarında kullanılan materyaller içerisinden seçilmiştir. $P l_{6}$ ve $P l_{A r g}$ dayanıklılık geni içeren hatların hassas hatlar ile melezlenmesi ve kendilenmesi sonucu elde edilen materyal ile ebeveyn hatları çalışma için kullanılmıştır. Hastalık testleri sonucu 30 birey dayanıkl1 $\mathrm{F}_{5}, \quad 30$ birey hassas $\mathrm{F}_{5}$ olarak belirlenmiştir ve bu bireyler markörün seçiciliğinin belirlenmesinde kullanılmıştır. Ayrıca 60 birey ise gruplandırılmadan ayırıcı olarak tespit edilen markörün doğrulanması amaciyla taramalarda kullanılmıştır. Toplamda $P l_{6}$ için (Dayanıklı ebeveyn:TT322, Hassas ebeveyn:9702-R, Melezler:K4-R-SN-28, 9702-R-SN-6) 120 adet $\mathrm{F}_{5}$ kademesindeki genotipler ve $P l_{A r g}$ için (Dayanıklı ebeveyn:RHA-419, Hassas ebeveyn:9758-R, Melezler:K3-R-SN-14, K3-R-SN-39) 120 adet $\mathrm{F}_{4}$ kademesindeki genotipler, hastalı testleri yapılarak bitki materyali olarak kullanılmıştır.

\section{Patojen Materyali}

Hastalık testinde kullanmak üzere inokülasyon için gerekli olan patojen materyali TTAE tarafindan Trakya Bölgesindeki mildiyö epidemisi görülen ayçiçeği ekiliş alanlarından, ayçiçeğinin 8-10 yapraklı döneminde Edirne, Tekirdağ ve 
Kırklareli'de 14 lokasyondan toplanmıştır. Toplanan patojen örnekleri inokülasyon öncesi $-80{ }^{\circ} \mathrm{C}^{\prime} \mathrm{de}$ muhafaza edilmiştir.

\section{Hastalık Testleri}

Hastalık testleri TTAE tarafından enstitü bünyesinde yapılmıştır. Test edilecek ayçiçeği materyaline ait tohumların yüzeyi \%1'lik $\mathrm{NaOCl}$ kullanılarak steril edilmiş ve saf su ile durulanarak çimlendirilmek üzere oda sıcaklığında karanlık bir ortamda 3-4 gün bekletilmiştir. Çimlenen tohumların kökçükleri $0,5-1 \mathrm{~cm}$ uzunluğa eriştiğinde hastalığın bulaştırılması için petriler içerisine konarak hazırlanan spor solüsyonuna bırakılmıştır. Spor solüsyonu hazırlığı için; toplanan hastalıklı bitki örnekleri kullanılmadan önce saf su içerisine bitki yapraklarından firça ile süpürülen patojen sporları yoğunluğu mikroskop altında thoma lamı yardımıyla belirlenmiş, 30000-50000 sporangium/ $\mathrm{ml}$ yoğunlukta spor solüsyonu oluşturulmuştur. Çimlendirilmiş bitkicikler spor solüsyonu içerisinde $16^{\circ} \mathrm{C}^{\prime}$ de $\quad 4-5$ saat bekletilmesinin ardından kum+perlit karışımından oluşan plastik bardaklara ekilmiş ve ortam sicaklığ $24^{\circ} \mathrm{C}$ ayarlanarak, 12 saat aydınlık-12 saat karanlık olacak şekilde ayarlanan kontrollü iklim odasında büyümeye bırakılmıştır. Bitkilerin ilk gerçek yaprakları 2-3mm büyüklüğe ulaştığında bardakların üstü \%100 nem ortamı sağlayabilmek için plastik poşetler ile hava almayacak şekilde kapatılmış, $16^{\circ} \mathrm{C}$ de $24-48$ saat bekletilerek hassas bitkilerde beyaz renkte gözle görülebilir spor oluşması sağlanmıştır. Dayanıklı bireylerde bu spor oluşumu gözlemlenmemiş olup hassas ve dayanıklı bireyler belirlenerek numaralandırılmış ve moleküler çalışma sonuçları ile karşılaştırma amaçlı kayıt altına alınmıştır (Evci ve ark., 2011; Spring, 2019).

\section{Moleküler Analizler}

$\mathrm{Bu}$ çalışma için yapılan tüm moleküler analizler, Trakya Üniversitesi Mühendislik Fakültesi Genetik ve Biyomühendislik Bölümü Biyoteknoloji Laboratuvarlarında gerçekleştirilmiştir.

\section{DNA İzolasyonu}

TTAE tarafindan hastalık testleri yapılan materyallerin ilk gerçek yapraklarından, örnek başına 150-200mg bitki dokusu olacak şekilde 2ml'lik tüplerin içerisine alınmıştır. Örnekler toplandıktan sonra $-196^{\circ} \mathrm{C}$ 'lik sıvı azot içerisine atılarak dondurulmuş ve $-20^{\circ} \mathrm{C}$ 'de DNA izolasyonu safhasına kadar muhafaza edilmiştir. Bitki materyaline ait yapraklardan alınan örneklerin DNA'lar1, Doyle ve Doyle (1990)'un CTAB yöntemleri modifiye edilerek izole edilmiştir (Porebski ve ark., 1997; Şimşek ve ark., 2008 ).

DNA miktar tayini için OPTIZZEN NanoQ Spektrofotometresi kullanılmış ve örnekler için DNA miktar1 ng/ $\mu \mathrm{l}$ cinsinden OD260/OD280 (nükleik asit saflığı için) oranına dikkat edilerek kaydedilmiştir. DNA miktarları dikkate alınarak DNA kalitesini tespit etmek ve DNA kırıkları olup olmadığını görebilmek için her örnekten yaklaşık 800 ng olacak şekilde \% 0,8 konsantrasyonlu, EtBr $(30 \mu 1 / L)$ (Etidyum bromür) içeren jele yüklemeler yapılmış ve $100 \mathrm{~V} \quad 80 \mathrm{~mA}$ akımda 1 saat yürütülmüştür. Elektroforezin ardından jel görüntüleme cihazında UV 1şık altında örneklerin DNA kalitesine bakılmıştır.

\section{Markör Çalışmaları}

Çalışma için seçilen $\mathrm{Pl}_{6}$ ve PlArg dayanıklılık genlerinin belirlenmesinde kullanılan markörler literatür taraması sonucunda belirlenmiş olup baz dizileri verilerek Sentromer DNA Teknolojileri firmasına sentezlettirilmiştir. Çalışmaya alınan markörlerin seçiminde, $P l$ genlerinin haritalandı $\breve{g}_{1}$ makalelerden yararlanılmış ve markörün gen bölgesine yakınlığına dikkat edilmiştir (Brahm ve ark., 2000; Bouzidi ve ark., 2002; Pankovic ve ark., 2007; Wieckhorst ve ark., 2010; Imerovski ve ark., 2014). Markörün gen bölgesine uzaklığına bağlı olarak rekombinasyon oranı değişmektedir. Bu oranı en aza indirmek için en yakın markörlerin kullanılması önemlidir. Bu nedenle genin $<5 \mathrm{cM}$ uzağında yer alan markörler çalışmaya dahil edilmiştir. Literatür çalışması sonucu $\mathrm{Pl}_{6}$ dayanıkl11ı geninin belirlenmesinde kullanımı uygun görülen HAP2, HAP3, ORS166 ve ORS1043 markörleri, PlArg dayanıklılık geninin belirlenmesinde ise ORS552, ORS662, ORS675, ORS716 markörleri seçilmiş ve farklı PCR içerikleri ve koşulları ile denemeler yapılmıştır. 
PCR içeriği olarak 1X PCR Buffer, $3 \mathrm{mM} \mathrm{MgCl}_{2}$, 0,4mM dNTPs, 0,6mM Primer F, 0,6mM Primer R, $1 \mathrm{U}$ Taq, $250 \mu \mathrm{g}$ BSA, 40ng DNA kullanılmıştır. PCR koşulları primer TM sicaklıklarına uygun 35 döngü olacak şekilde uygulanmıştır. Elde edilen PCR ürünlerinden bazıları PCR çalışmasının başarılı olup olmadığını görmek için kapiller elektroforeze yüklenmeden önce jel elektroforezde yürütülerek görüntülenmiş ve başarılı olanlar kapiller elektroforeze yüklenmiştir. Başarılı PCR ürünleri Advance Analytical Fragment Analyzer kapiller elektroforeze yüklenerek fragment boyutları ölçülmüş ve fragment boyutlarına göre karşılaştırmalar yapılarak seleksiyonda kullanılabilirlikleri test edilmiştir.

\section{BULGULAR}

\section{$P_{6}$ için Kullanılan Markörlerin Sonuçları}

Yapılan çalışma sonucu ORS166 markörü ile ebeveyn ve $\mathrm{F}_{5}$ populasyonuna ait 30 dayanıklı ve 30 hassas bireyde $343 \mathrm{bp}, 354 \mathrm{bp}$, 369bp ve $383 \mathrm{bp}$ bantları çoğaltılmış olup herhangi bir ayırt edici DNA fragmenti gözlenmemiştir. ORS1043 markörü ile ebeveyn ve $\mathrm{F}_{5}$ populasyonuna ait 30 dayanıklı ve 30 hassas bireyde 188bp, 200bp, 209bp, 253bp ve $273 \mathrm{bp}$ boyutunda DNA fragmentleri çoğaltılmıştır. Bunlardan 188bp büyüklüğündeki fragmentin sadece dayanıklı bireylerde bulunduğu gözlenmiştir. Bu durum ORS1043 markörünün $P l_{6}$ dayanıklılık geninin belirlenmesinde seçici olarak kullanılabileceğini ortaya koymaktadır. ORS1043 primerine göre dayanıklılık profili gösteren F5 örnekleri ve göstermeyen örnekler hastalık testleri ile de uyumlu sonuçlar ortaya koymuştur.

HAP2 markörü ile ebeveyn ve $F_{5}$ popülasyonuna ait 30 dayanıklı ve 30 hassas bireyde $370 \mathrm{bp}, 439 \mathrm{bp}$, $449 \mathrm{bp}$ ve $682 \mathrm{bp}$ DNA fragmentleri çoğaltılmış olup herhangi bir ayırt edicilik gözlenmemiştir. HAP3 markörü ile yapılan çalışma sonucu, ebeveyn ve bu ebeveynlerin F5 kademesindeki popülasyonuna ait 30 dayanıklı ve 30 hassas bireyde $1165 \mathrm{bp}, 1348$ bp, 1610 bp, 1725 bp ve 2100 bp büyüklüğünde DNA fragmentleri çoğaltılmıştır. Bunlardan 1348 bp büyüklügündeki DNA fragmentinin dayanıklılık karakteri ile birlikte döllerde açılma olduğu, hassas bireylerde ise bu fragmentin bulunmadığ edilmiştir. 1348 bp'lik DNA fragmentinin $\mathrm{Pl}_{6}$ geni taşıyan bireylerin belirlenmesinde uygun bir markör olduğu ve MAS amaçlı kullanılabilir nitelikte olduğu tespit edilmiştir.

\section{$P l_{A r g}$ için Kullanılan Markörlerin Sonuçları}

Yapılan çalışma sonucu ORS716 markörü ile 302bp, 321bp, 342bp, 350bp ve 371bp, ORS662 markörü ile 316bp, 335bp, ORS552 markörü ile 192bp, 235bp, 240bp, ORS675 markörü ile 237bp, 277bp DNA fragmentleri çoğaltılmış olup, herhangi bir ayırt edicilik gözlenmemiştir.

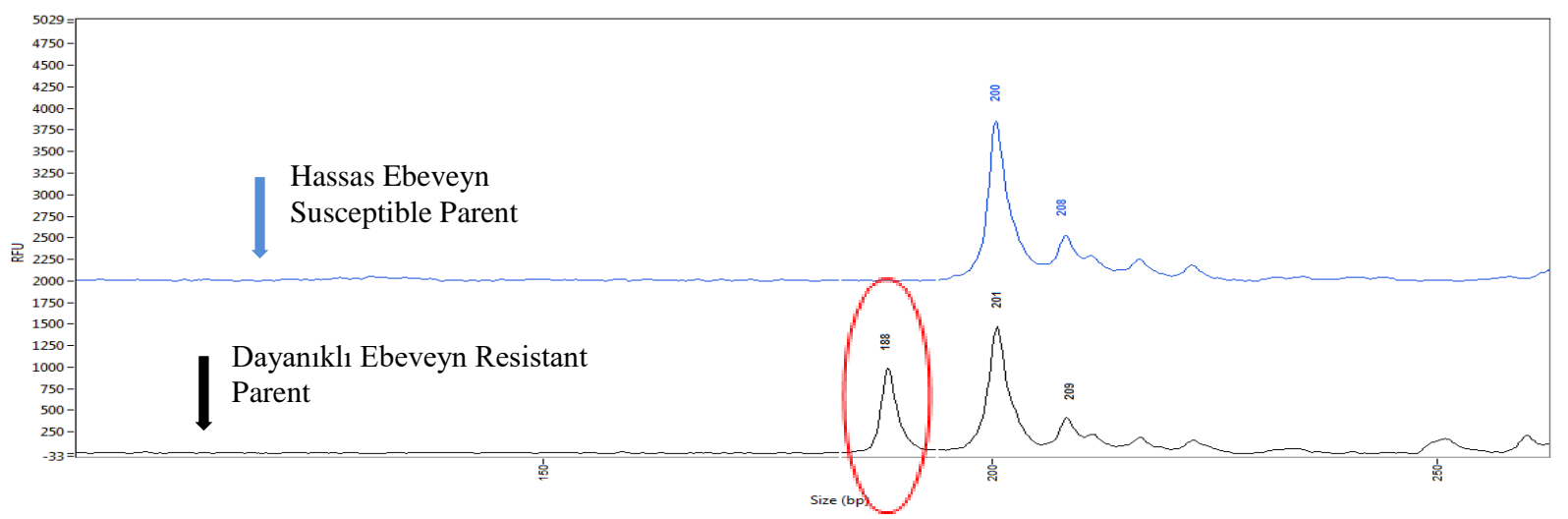

Şekil 1. Pl6 ORS1043 markörü ile dayanıklı ve hassas ebeveynler arasındaki fark.

Figure 1. Difference between susceptible and resistance parents with ORS1043 Pl6 marker. 


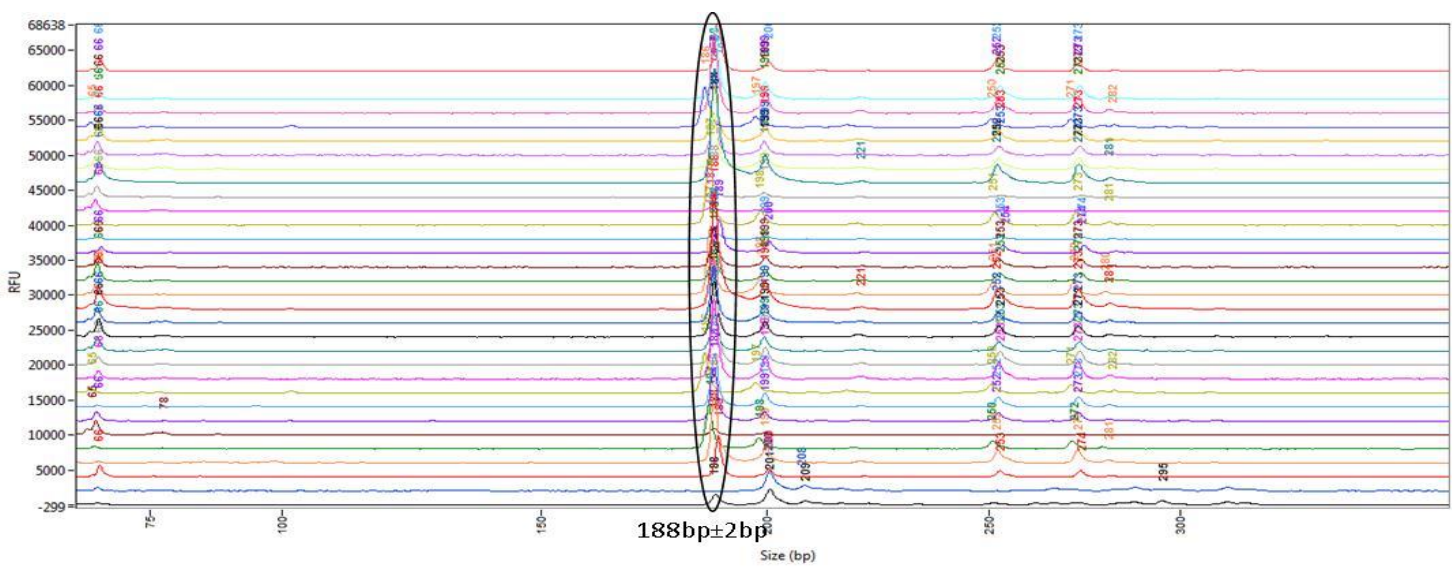

Şekil 2. Pl6 ORS1043 markörü kullanılarak yapılan PCR sonucu kapiller elektroforez görüntüsü, ebeveynler ve dayanıklılık profiline sahip F5 bireyler.

Figure 2. Kapiller results with $\mathrm{Pl}_{6}$ ORS1043 marker, parents and F5 individuals with resistance profile.

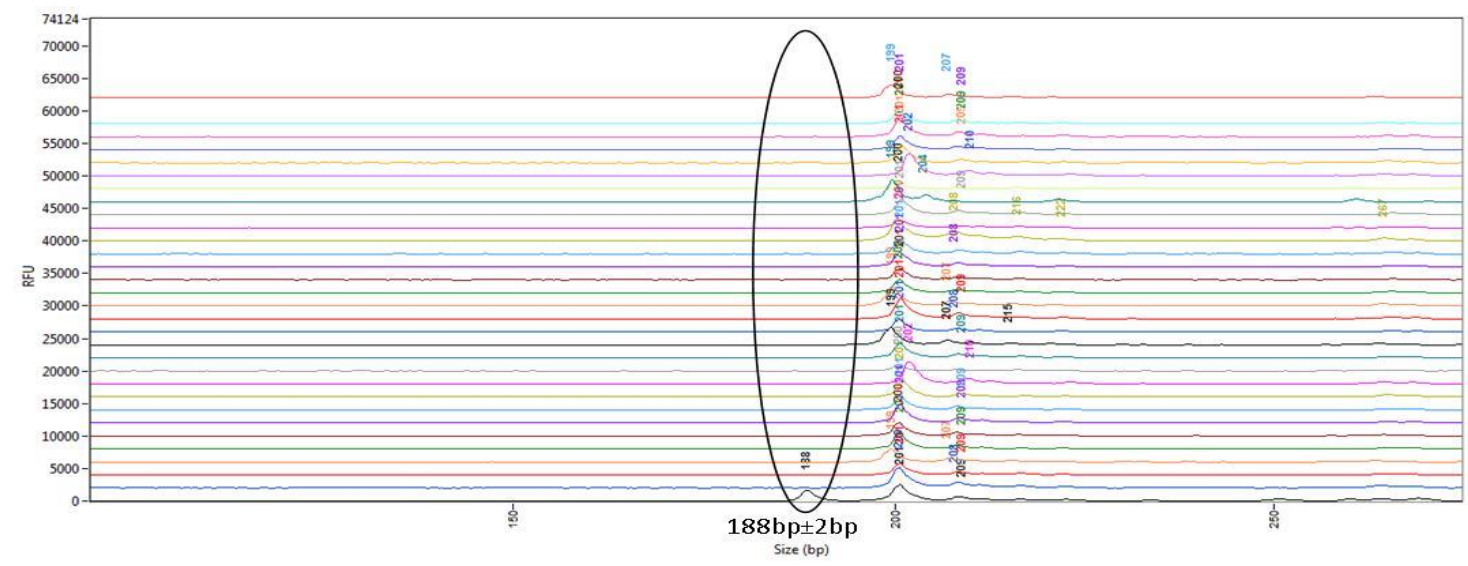

Şekil 3. Pl6 ORS1043 markörü kullanılarak yapılan PCR sonucu kapiller elektroforez görüntüsü, ebeveynler ve hassas profile sahip F5 bireyler.

Figure 3. Capillary results with $\mathrm{Pl}_{6}$ ORS1043 marker, parents and F5 individuals with susceptible profile.

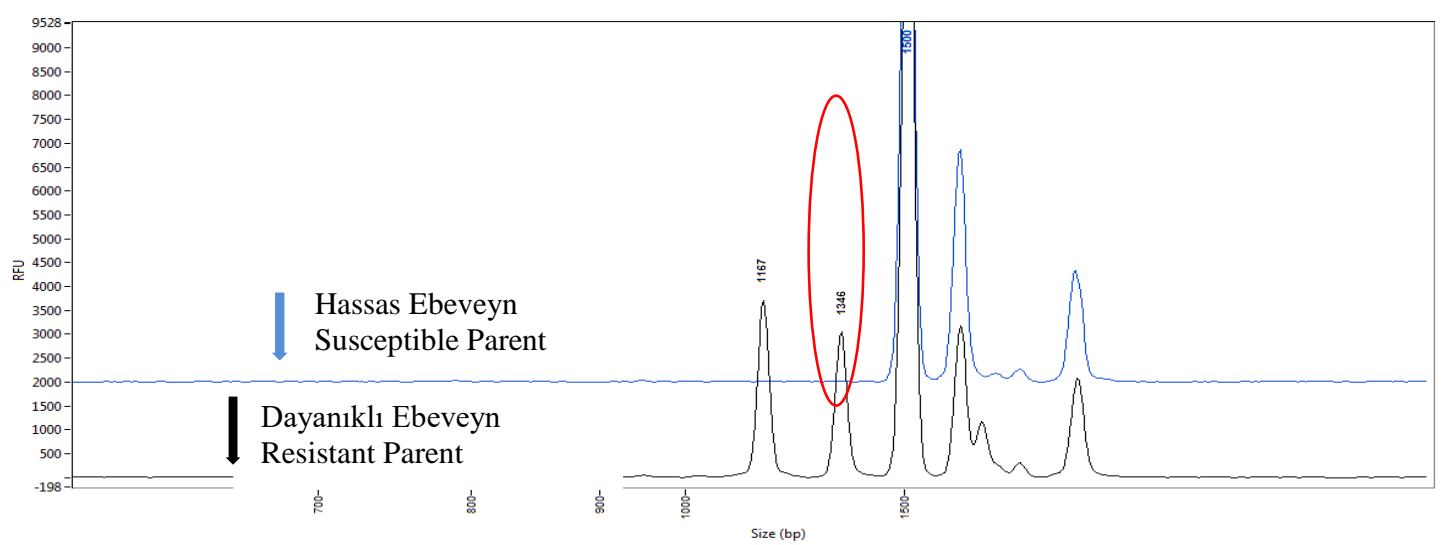

Şekil 4. Pl6 HAP3 markörü ile dayanıklı ve hassas ebeveynler arasındaki fark.

Figure 4. Differences between susceptible and resistant parents with HAP3 Pl6 marker. 
E. AKPINAR, S. HASANÇEBİ, Y. KAYA: AYĊICCEĞINDE MILDIYYÖ [Plasmopara halstedii (Farl.) Berl. and de Toni] HASTALIĞINA DAYANIKLI GENOTIPLERIN MOLEKÜLER MARKÖRLER KULLANILARAK BELIRLENMESI

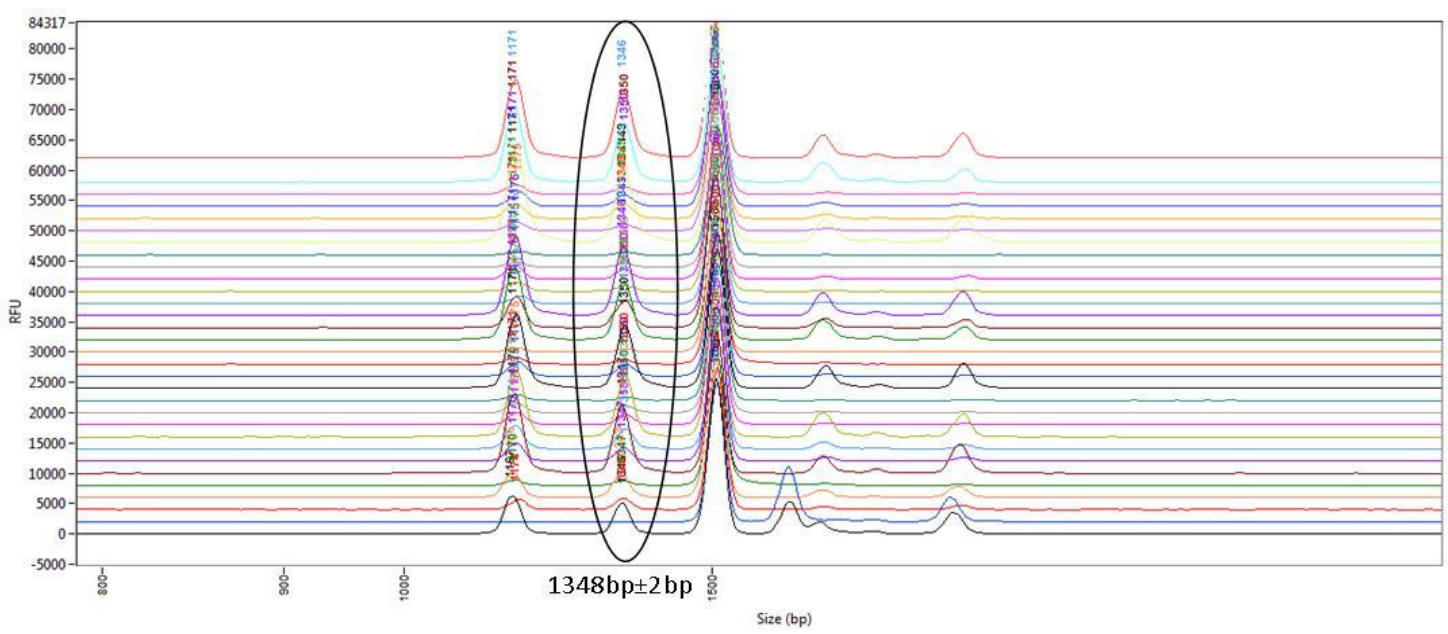

Şekil 5. Pl6 HAP3 markörü kullanılarak yapılan PCR sonucu kapiller elektroforez görüntüsü, ebeveynler ve dayanıklılık profiline sahip F5 bireyler.

Figure 5. Capillary results with Pl6 HAP3 marker, parents and F5 individuals with resistance profile.

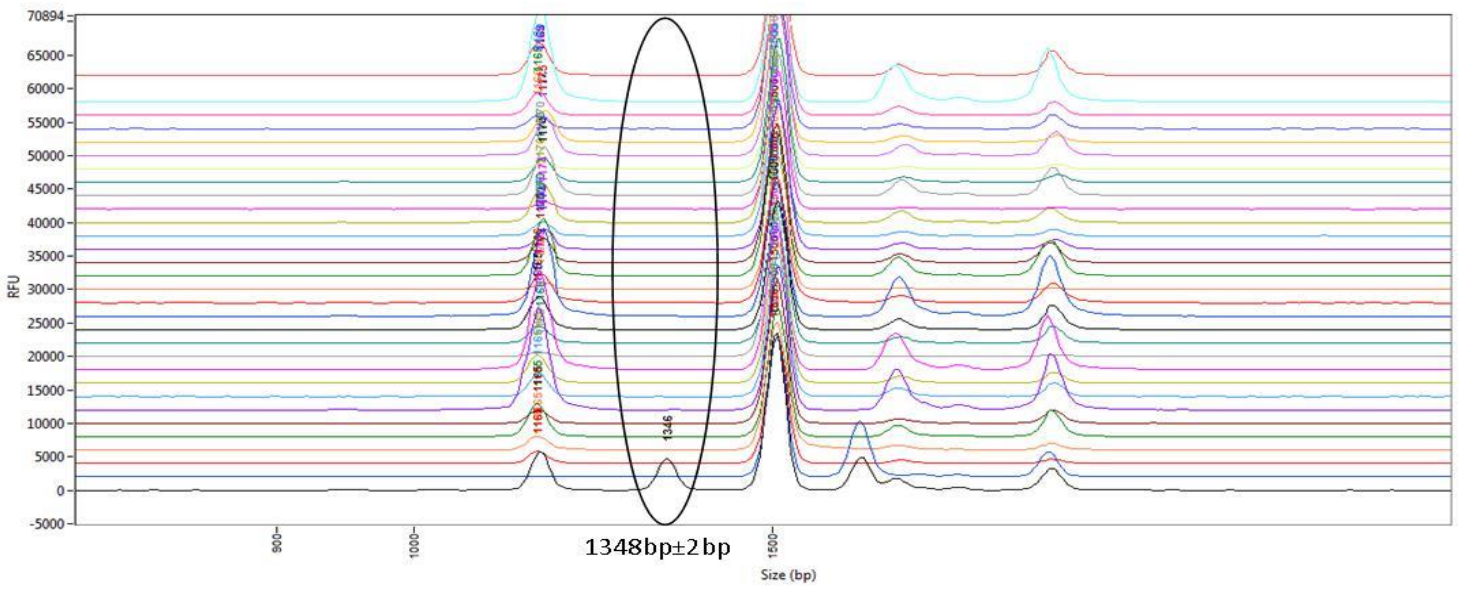

Şekil 6. Pl6 HAP3 markörü kullanılarak yapılan PCR sonucu kapiller elektroforez görüntüsü, ebeveynler ve hassas profile sahip F5 bireyler.

Figure 6. Capillary results with Pl6 HAP3 marker, parents and F5 individuals with susceptible profile.

\section{TARTIŞMA}

$\mathrm{Bu}$ çalışmada TTAE'den elde edilen bitki materyalleri ile yine TTAE'nün yıllar içerisinde topladığı $P$. halstedii patojenleri kullanılarak bitki materyalleri üstünde hastalık testleri yapılmıştır. Hastalık testi uygulanmasının nedeni çalışma sonunda moleküler düzeyde ayrım yapabildiği tespit edilen markörlerin test edilerek doğruluğunun onaylanmasi amaciyla kullanılmasindan kaynaklanmaktadır. Bu nedenle aday markörlerin test edilmesi için hastalık testi sonrası dayanıklı ve hassas olarak sınıflandırılan altmışar genotip kullanılmış, dayanıklılık profilini başarıyla tespit ettiği düşünülen markörler ayrıca hastalık testi yapılmış 60'ar farklı genotipte daha test edilerek sağlaması yapılmıştır. Moleküler çalışmaları yapılacak $P l$ genlerinin seçimi, bölgedeki $P$. halstedii rrkları için herhangi bir ırk ayrımı çalışması yapılmadığından dolayı, hali hazırda TTAE tarafından klasik ıslah çalışmalarında kullanılan mevcut ebeveyn hatlarının sahip olduğu bilinen $\mathrm{Pl}_{6}$ ve PlArg genleri tercih edilmiştir.

Kullanılan bitki materyali için literatür taraması yapılarak moleküler destekli ıslah çalışmalarında $P$. halstedii patojeninin neden olduğu mildiyö hastalı̆̆ına dayanıklılık sağlayan $P l_{6}$ ve PlArg 
genleri taşıyan çeşitlerin geliştirilmesinde kullanılabilecek aday markörler belirlenmiştir. Dayanıklılık 1slahında kullanılacak aday markörlerin ve yöntemin belirlenmesi için eldeki materyal ile ilgili bilgi, araştırmanın amacı, sahip olunan laboratuvar kaynakları, maliyet, zaman ve günümüzde tercih edilen yöntemler ve markörler gibi ölçütler göz önünde tutularak karar verilmiştir.

Usatov ve ark. (2014), $P l_{6}$ dayanıklılık geni için 16 ayçiçeği hattında $P$. halstedii 1rk 330 ve 1 rk 710 için 9 STS markörü test etmiş ve HAP2 markörü için $1200 \mathrm{bp}$, HAP 3 markörü için 1800 bp boyutlarında, dayanıklılık için ayırt edici DNA fragmentleri raporlamışlardır. Aynı markörler için Bouzidi ve ark. (2002), ayçiçeği hattı HA335 için yaptıkları çalışmada 13 STS markörü test etmiş, HAP3 markörü için 700 bp boyutunda dayanıklılık için ayırıcı DNA fragmenti tespit ettiklerini raporlarken, HAP2 için ise ayırt edici bir fragment raporlamamışlardır. Pankovic ve ark. (2007) yaptıkları çalışmada, $P$. halstedii ırk 730 patojeni için HAP3 markörünün 1720 bp büyüklüğündeki DNA fragmenti ile dayanıklı genotipleri ayırt edebildiğini ve MAS için kullanılabileceğini raporlamıştır. Yapılan farklı haritalama çalışmalarında HAP2 ve HAP3 markörlerinın gen bölgesine olan uzaklıklarının $3.3 \mathrm{cM}$ ile $11 \mathrm{cM}$ arasında oldukları görülmüştür. Bu çalışmada elde edilen sonuç ile HAP2 markörü için Bouzidi ve ark. (2002) ve Pankovic ve ark. (2007)'in sonuçlarına benzer şekilde genotipler arasında dayanıkl1lı ayırıc1 bir DNA fragmentine rastlanamamıştır. HAP3 markörü için ise, Pankovic ve ark. (2007)'ın çalışmasına paralel olarak 1448 bp büyüklüğünde DNA fragmenti $P l_{6}$ geninden kaynaklanan dayanıklılık için ayırt edici bulunmuştur. $\mathrm{Bu}$ araştırmada ve diğer araştırmalarda bulunan dayanıklı1ık ayırıcı fragment büyüklüğü, kullanılan dayanıklılık kaynağı ebeveyn hatlarının farklı olmasından kaynaklanabileceği düşünülmektedir.

Yine Pankovic ve ark. (2007)'ın çalışmasında, $\mathrm{Pl}_{6}$ dayanıkl1lık geni ile ilgili ORS166 ve ORS1043 SSR primerlerinin dayanıklılık tespitinde kullanılabileceğini belirtmiş, fakat dayanıklılık için ayırt edici fragmentlerin boyutundan bahsedilmemiştir.
Bizim çalışmamız sonucu ORS166 için ayırt edici bir fragment gözlenememesine rağmen ORS1043 için 188 bp büyüklüğünde DNA fragmentinin $P l_{6}$ geninden kaynaklı dayanıklılığın tespitinde başarılı olduğu görülmüştür. $\mathrm{Pl}_{6}$ geninden kaynaklı dayanıklı1ığın tespiti için MAS'da kullanılabilecek 2 adet markör (HAP3 ve ORS1043) bu çalışma sonucunda belirlenmiştir. HAP2 ve ORS166 markörlerinin dayanıklılık tespitinde başarısız olmalarının nedeni, diğer çalışmalarda kullanılan ebeveyn hatları ile bu çalışmada kullanılan ebeveyn hatlarının farklılığı olabilir.

Dussle ve ark. (2004), yabani ayçiçeği Helianthus argophyllus 1575-2 hattını dayanıklılık kaynağ olarak kullanarak PlArg geni için ORS662 markörünü gen bölgesine en yakın SSR olarak 1,9 cM uzaklıkta haritalandırmışlardır. Aynı dayanıklılık kaynağını kullanarak Wieckhorst ve ark. (2010), ORS662 ve ORS716 markörlerini $0,3 \mathrm{cM}$ uzaklıkta raporlamışlardır. Imerovski ve ark. (2014), PlArg dayanıklılık geninin Helianthus argophyllus 1575-2'den kültür türüne aktarılmas1 ile elde edilen RHA419 hattında yaptığı çalışmalar ile ORS716 markörünün 5,2cM uzaklıkta olduğunu ve 303 bp boyutunda ayırt edici bir fragment verdiğini gözlemlemişlerdir. Ayrıca ORS675 markörü ile hassas genotiplerde 275 bp boyutunda fragment gözlenirken dayanıklı genotiplerde DNA fragmenti gözlenmediği belirtilmiştir.

$\mathrm{Bu}$ çalışmada kullanılan dayanıklılık kaynağı RHA419 ile PlArg için seçilen aday markörlerin hiçbirinde dayanıklılığı ayırt edecek DNA fragmenti gözlenememiştir. Imerovski ve ark. (2014)'nın çalışmasında, ORS716 markörü ile çoğaltılan 303 bp boyutundaki fragment bizim çalışmamızda da aynı fragment büyüklüğü dayanıklılık kaynağında gözlemlenmesine rağmen, hastalık testleri yapılan tüm hassas ve dayanıklı genotiplerde aynı fragment çoğaltılmış, bu nedenle bir ayırt edicilik gözlemlenememiştir. Yine Imerovski ve ark. (2014)'nın ORS675 için belirttikleri hassas genotipi ayırt edici 275 bp büyüklüğündeki fragment dayanıklı genotipler dahil tüm genotiplerde görülmüş, hassas ve dayanıklı ebeveynlerde de aynı fragmentlerin çoğaltıldığı gözlemlenmiştir. 
PlArg için kullanılan diğer markörlerdan ORS 662 dayanıklı ebeveynde 316 bp ve 335 bp boyutunda fragmentler gözlemlenirken hassas ebeveynde sadece 335 bp büyüklüğündeki çoğaltılmıştır. Hastalık testleri yapılmış melezlerde ORS662 markörü hem hassas genotipteki bireylerde hem de dayanıklı genotipteki bireylerde anlamlı olmayan oranda görüldüğü için dayanıklılık ayırt edici markör olarak görülmemiştir. Test edilen diğer ORS552 markörü çoğaltılan DNA fragmentleri dikkate alınıp hassas ve dayanıklı genotiplerde kontrol edildiğinde dayanıklılık ayırt edici gözükmemektedir.

\section{SONUÇ ve ÖNERILLER}

Yapılan çalışmada PlArg için denenen markörlerin, literatürde sıkça kullanılan RHA419 dayanıklılık kaynağı ile denenmesine rağmen test edilen markörlerin dayanıklılığı ayırt edememesinin başlıca nedeninin ebeveyn kaynaklı olmadığ düşünülmektedir. Bu durumda RHA419 melezlerinde seçiciliği birden çok kez kanıtlanan özellikle ORS716 markörünün bu çalışmada başarısız olması, muhtemelen ilk melezleme sirasinda markör ile gen arasındaki bölgede rekombinasyon kaynaklı ayrılma yaşanması olduğu düşünülmektedir.

Yapılan çalışmalar sonucunda $P l_{6}$ için sslah çalışmalarında kullanılabilecek 2 adet markör başarıyla tespit edilmiş olup, bu markörler

\section{LİTERATÜR LİSTESI}

Aksoy, M. H. ve A. Öz. 2012. Bakteriyel patojenlere karş1 bitkilerdeki dayanıklılık mekanizmaları. Anadolu Tarım Bilimleri Dergisi 165-173.

Aktaş, Y. L. ve A. Güven. 2005. Bitki savunma sistemlerinde hormonal sinyal moleküller ve çapraz iletişimleri. Journal of Arts and Sciences 1 (3): 1-12.

Anonim. 2008. TAGEM. Zirai Mücadele Teknik Talimatı. T.A. Müdürlüğ̈̈, Endüstri Bitkileri Hastalıkları. 8-12.

Anonim. 2014. Gümrük ve Ticaret Bakanlığı. Ayçiçeği Raporu 2014. Kooperatifçilik Genel Müdürlüğü.

Bretting, P. K., and M. P. Widrlechner. 1995. Genetic markers and plant genetic resource management. Edited by $\mathrm{J}$. Janick. John Wiley \& Son Inc. Canada. 11-86. ISBN: 978-0-471-57343-2. kullanılarak ileride ıslah çalışmalarında seleksiyon ve gen piramitleme çalışmalarının daha hızlı ve güvenilir olmasını sağlanabilecektir.

PlArg için yapılan çalışmalar sonucunda tarama yapılan bitki materyali için çalışmada kullanılan dört markörün dayanıklılık profilinin tespitinde ayırıcı olmadığı görülmüştür. Ayırıcı dayanıklılık profilinin tespiti için daha fazla markör ile araştırma yapılması gerekmektedir.

Dayanıklılık ıslahında klasik ıslah çalı̧̧malarına kıyasla moleküler destekli 1slah yöntemi daha ekonomik, doğru ve hızlı 1slah yapılmasına yardımcı olacaktır. Bunun gerçekleştirilebilmesi için ıslah programlarını yürüten kurumların moleküler çalışmalar için yatırım yapması ya da bu bilgi ve donanıma sahip kurumlardan destek alması gerekmektedir. Mildiyö için ise, dayanıklılık testlerinin ve markör çalışmalarının daha sağlıklı yapılabilmesi için ülkemizdeki patojen ırklarının mutlaka ayırt edilmesi gerekmektedir.

\section{TEŞEKKÜR}

Yazarlar, TUBAP 2016/300 nolu projeye verilen desteklerinden dolayı T.C. Trakya Tarımsal Araştırma Enstitüsü ve Trakya Üniversitesi Bilimsel Araştırma Projeleri Birimi'ne teşekkür etmektedir.

Bouzidi, M. F., S. Badaoui, F. Cambon, F. Vear, D. T. De Labrouhe, P. Nicolas, and S. Mouzeyar. 2002. Molecular analysis of a major locus for resistance to downy mildew in sunflower with specific PCRbased markers. Theoretical and Applied Genetics 104 (4): 592-600.

Brahm, L., T. Rocher, and W. Friedt. 2000. PCR-based markers facilitating marker assisted selection in sunflower for resistance to downy mildew. Crop Science 40: 676-682.

Doyle, J. J., and J. L. Doyle. 1990. Isolation of plant DNA from fresh tissue. Focus 12: 13-15.

Dussle, C. M., V. Hahn, S. J. Knapp, and E. Bauer. 2004. PlArg from Helianthus argophyllus is unlinked to other known downy mildew resistance genes in sunflower. Theor Appl Genetics 109 (5): 1083-1086. 
Evci, G., V. Pekcan, M. I. Yilmaz, K. Akın, Y. Kaya. 2011 Bazı ayçiçeği hatlarının Trakya Bölgesindeki ayçiçeği mildiyösüne [(Plasmopara Halstedii (Farl.) Berl. \& De Toni.)] dayanıklılıklarının belirlenmesi. Anadolu 21 (1): 36-43.

Filiz, E., B. S. Özdemir, M. Tuna, and H. Budak. 2009. Diploid Brachypodium distachyon of Turkey: Moleculer and Morphological Analysis. 83-89. In: T. Yamada ve G. Spangenberg (Eds.). The Proceedings of the 5th International Symposium on the Molecular Breeding of Forage and Turf. Springer Publishing.

Gulya, T. J. 2007. Distribution of Plasmopara halstedii (Farl.) Berl. and de Toni races from sunflower around the World. pp.121-134. Proc 2nd Int Downy Mildew Symp "Advances in Downy Mildew Research". July 2-6. Olomouc, Czech Republic.

Hvarleva, Tz., I. Tarpomanova, M. Hristova-Cherbadji, M. Hristov, A. Bakalova, A. Atanassov, and I. Atanasov. 2009. Toward marker assisted selection for fungal disease resistance in sunflower. utilization of $H$. bolanderi as a source of resistance to downy mildew. Biotechnol. EQ. 23: 1427-1430.

Imerovski, I., A. Dimitrijevic, D. Miladinovic, S. Jocic, B. Dedic, S. Cvejic, and G. Surlan-Momirovic. 2014. Identification and validation of breeder-friendly DNA markers for Plarg gene in sunflower Mol Breeding 34: 779-788.

İmraz, G., F. Özdemir, N. M. Taş, B. Ercan, İ. Topal ve M. S. Karaca. 2015. Bitkilerde fungal ve bakteriyel hastalıklara karşı dayanıklılık genleri ve sinyal iletimi. Elektronik Mikrobiyoloji Dergisi 13 (1): 1227.

Jocic, S., S. Cvejic, N. Hladni, D. Miladinovic, and V. Miklic. 2010. Development of sunflower genotypes resistant to downy mildew. Helia 33: 173-180.

Jones, J. D. G., and J. L. Dangl. 2006. The plant immune system. Nature 444: 323-329.

Kaya, Y. 2004. Ayçiçeği biyoteknolojisinde son gelişmeler ve 1slahında kullanım olanakları. Trakya Üniversitesi Fen Bilimleri Dergisi 5 (2): 141-147.

Kaya, Y., S. Jocic, and D. Miladinovic. 2012. Sunflower. Vol. 1. pp. 85-130. In: S. K. Gupta (Ed.) Technological Innovations in Major World Oil Crops.

Kaya, Y., I. Balalic, and V. Miklic. 2015. Eastern Europe Perspectives on Sunflower Production and Processing. pp. 575-638. In: N. Dunford, E. M. Force (Eds.) Sunflower: Chemistry, Production, Processing, and Utilization. 710 pages. AOCS (American Oil Chemistry Society).

Liu, Z., T. J. Gulya, G. J. Seiler, B. A. Vick, and C. C. Jan, 2012. Molecular mapping of the $\mathrm{Pl}_{16}$ downy mildew resistance gene from HA-R4 to facilitate markerassisted selection in sunflower. Theoretical and Applied Genetics 125: 121-131.
Ma, G. J., S. G. Markell, Q. J. Song, and L. L. Qi. 2017. Genotyping-by-sequencing targeting of a novel downy mildew resistance gene $\mathrm{Pl}_{20}$ from wild Helianthus argophyllus for sunflower (Helianthus annuus L.). Theoretical and Applied Genetics 130: 1519-1529.

Mouzeyar, S., P. Roeckel-Drevet, L. Gentzbittel, J. Philippon, D. Tourvieille De Labrouhe, F. Vear, and P. Nicolas. 1995. RFLP and RAPD mapping of the sunflower P11 locus for resistance to Plasmopara halstedii (Farl.) Berl. and de Toni race 1. Theoretical and Applied Genetics 5: 133-737.

Pankovic, D., N. Radovanovic, S. Jocic, Z. Satovic, and D. Skoric. 2007. Development of co-dominant amplified polymorphic sequence markers for resistance to sunflower downy mildew race 730 . Plant Breeding 126: 440-444.

Qi, L. L., Y. M. Long, C. C. Jan, G. J. Ma, and T. J. Gulya. 2015. $\mathrm{Pl}_{17}$ is a novel gene independent of known downy mildew resistance genes in the cultivated sunflower (Helianthus annuus L.). Theoretical and Applied Genetics 128 (4): 757-767.

Qi, L. L., M. E. Foley, X. W. Cai, and T. J. Gulya. 2016. Genetics and mapping of a novel downy mildew resistance gene, $\mathrm{Pl}_{18}$, introgressed from wild Helianthus argophyllus into cultivated sunflower (Helianthus annuus L.). Theoretical and Applied Genetics 129 (4): 741-752.

Qi, L. L., Z. I. Talukder, B. S. Hulke, and M. E. Foley. 2017. Development and dissection of diagnostic SNP markers for the downy mildew resistance genes $\mathrm{Pl}_{\mathrm{Arg}}$ and $\mathrm{Pl}_{8}$ and marker-assisted gene pyramiding in sunflower (Helianthus annuus L.). Mol. Genet. Genomics 292: 1-13.

Porebski, S., L. G. Bailey, and B. R. Baum. 1997. Modification of a CTAB DNA extraction protocol for plants containing high polysaccharide and polyphenol components. Plant Mol Biol Rep. 15: 815.

Pérez-Vich, B., and S. T. Berry. 2010. Molecular breeding. pp 221-252 In: Hu J, Seiler G, Kole C (Eds.) Genetics, genomics and breeding of sunflower. CRC Science, Boca Raton, FL.

Ruiz, M. L., J. Dominguez, and M. Vara. 2000. Evaluation of Spanish Isolates of Plasmopara halstedii (Farl.) Berl. and de Toni for Tolarance to Metalaxyl, Helia 23: $33-38$

Şimşek, Ö., F. E. Karaat, S. Serçe ve Y. A. Kaçar. 2008. Bazı meyve türlerinde dna izolasyon yöntemlerinin etkinliğinin karşılaştırılması. Derim 25: 59-69.

Škorić, D. 2012. The genetics of sunflower. pp 1-125. In: Kovacevic Z, Skoric D, Sakac Z (Eds.) Sunflower genetics and breeding-international monogram. Serbian Acad. Sci, Serbia. 
E. AKPINAR, S. HASANÇEBİ, Y. KAYA: AYÇIÇEĞİNDE MILDIIYÖ [Plasmopara halstedii (Farl.) Berl. and de Toni] HASTALIĞINA DAYANIKLI GENOTIPLERIN MOLEKÜLER MARKÖRLER KULLANILARAK BELIRLENMESİ

Sönmezoğlu, Ö. A., A. Yıldırım, T. E. Güleç ve N. Kandemir. 2010. Markör destekli seleksiyonun buğday 1slahında kullanımı. GOÜ Ziraat Fakültesi Dergisi 27 (1): 105-112.

Spring, O. 2019. Spreading and global pathogenic diversity of sunflower downy mildew - Review. Plant Protection Science 55 (3): 149-158.

Tan, A. S. 2010. Identification of rust (Puccinia helianthi Schw.) races in sunflower (Helianthus annuus L.) in Turkey. Helia 33 (53): 181-190.

Trojanová, Z., M. Sedlarova, T. J. Gulya, and A. Lebeda. 2017. Methodology of virulence screening and race characterization of Plasmopara halstedii (Farl.) Berl. and de Toni, and resistance evaluation in sunflower-a Review. Plant Pathology 66: 171-185.

Usatov, A. V., A. I. Klimenko, K. V. Azarin, O. F. Gorbachenko, N. V. Markin, V. E. Tikhobaeva, Y. A. Kolosov, O. A. Usatova, S. Y. Bakoev, M. Y. Bibov, and L. V. Getmantseva. 2014. DNA markers of sunflower resistance to the downy mildew [(Plasmopara halstedii (Farl.) Berl. and de Toni]. American Journal of Biochemistry and Biotechnology 10 (2): 125-129.
Viranyi, F., T. J. Gulya, and D. T. Labrouhe. 2015. Recent changes in the pathogenic variability of Plasmopara halstedii (Farl.) Berl. and de Toni (sunflower downy mildew) populations from different continents. Helia 38: $149-162$.

Wieckhorst, S. 2011. Characterization of the PlArg Locus Mediating resistance against Plasmopara halstedii (Farl.) Berl. and de Toni in Sunflower. PhD thesis. Technische Universität München.

Wieckhorst, S., E. Backlava, C. M. Dussle, S. Tang, V. Hahn, and E. Bauer. 2010. Fine mapping of the sunflower resistance locus PlARG introduced from the wild species Helianthus argophyllus. Theoretical and Applied Genetics 121 (8): 1633-1644.

Zhang, Z. W., G. J. Ma, J. Zhao, S. G. Markell, and L. 1. Qi. 2017. Discovery and introgression of the wild sunflower-derived novel downy mildew resistance gene $\mathrm{Pl}_{19}$ in confection sunflower (Helianthus annuus L.). Theoretical and Applied Genetics 130 (1): 29-39. 